\title{
Stability of mixtures of ondansetron and haloperidol stored in infusors at different temperatures
}

\author{
María Espinosa-Bosch, ${ }^{1}$ Fuensanta Sanchez-Rojas, ${ }^{2}$ Catalina Bosch-Ojeda ${ }^{2}$
}

${ }^{1}$ UGC Pharmacy, Regional University Hospital of Málaga, Málaga, Spain ${ }^{2}$ Department of Analytical Chemistry, Faculty of Sciences, University of Málaga, Málaga, Spain

\section{Correspondence to}

Dr Fuensanta Sanchez-Rojas, Department of Analytical Chemistry, Faculty of Sciences, University of Málaga, Málaga 29071,Spain; fsanchezr@ uma.es

Received 27 September 2017 Revised 27 November 2017 Accepted 7 December 2017 Published Online First 27 January 2018

EAHP Statement 6: Education and Research.
Check for updates

To cite: Espinosa-Bosch M, Sanchez-Rojas F, BoschOjeda C. Eur J Hosp Pharm 2018:25:e134-e138.

\section{ABSTRACT}

Background and objective Mixing different drugs for use in continuous infusion systems is a common practice in palliative care, but analytical study of compatibility and stability is not always available. The objective of this work is to study the stability of solutions of ondansetron and haloperidol at different concentrations and temperatures all prepared in $0.9 \% \mathrm{NaCl}$ and stored in infusors, with all cases protected from light.

Materials and methods The high performance liquid chromatography-Ultraviolet (HPLC-UV) method was employed for the determination of the drugs. The concentrations of the admixtures were $0.15-0.25 \mathrm{mg} /$ $\mathrm{mL}$ and $0.3-0.4 \mathrm{mg} / \mathrm{mL}$ of haloperidol and ondansetron, respectively, with a storage temperature of $25^{\circ} \mathrm{C}$ and $37^{\circ} \mathrm{C}$.

Results All solutions were initially clear and colourless, but visible particles appear, in all cases, into the infusers after 2 days since their preparation.

Conclusion From the results obtained we can conclude that the mixtures prepared in the conditions previously described are stable less than 48 hours.

\section{INTRODUCTION}

The administration of drugs by subcutaneous infusion is routinely practised in palliative medicine. The WHO defines palliative care as 'an approach that improves the quality of life of patients and their families facing the problem associated with life-threatening illness, through the prevention and relief of suffering by means of early identification and impeccable assessment and treatment of pain and other problems, physical, psychosocial and spiritual'. ${ }^{1}$ Their priority is to treat the physical symptoms caused by the progression of disease or the side effects of its treatment. To obtain optimal symptom control in these patients, the simultaneous administration of more than one drug is often required. ${ }^{2}$ However, there are few published data on the compatibility and stability of drugs when administered together by this method.

When combinations of drugs are administered via subcutaneous infusion, drug incompatibility or loss of stability can occur. Incompatibility might cause drug precipitation or crystallisation, resulting in the blockage of the cannula, skin irritation and poor absorption. ${ }^{3}$ Physical and chemical instability may present a problem due to drug-drug, drugdiluent and drug-container interactions. Storage conditions are also important because the mixture is not usually administered as soon as it is prepared. Physical incompatibilities result in visible (precipitate, colour change, gas production) and invisible (subvisible particles, variations in $\mathrm{pH}$ ) reactions.
Chemical incompatibilities can lead to a decrease in drug bioavailability, drug degradation and/or production of toxic products.

In the literature there are studies that have evaluated the compatibility and stability of various drug mixtures under different experimental conditions $^{4-12}$; however, it is necessary to extend this research to other mixtures that can be used in palliative care, the compatibility and stability of which have not yet been established. ${ }^{13}$

Ondansetron is an antagonist of 5-hydroxytryptamine (serotonin) subtype $3\left(5-\mathrm{HT}_{3}\right)$ receptors. These receptors are located at the periphery of the vagal nerve terminals and at the central level in the postrema area of the brain. Cytotoxic drugs and radiation damage the gastric mucosa, causing serotonin release from cells of the gastrointestinal tract. Stimulation of $5-\mathrm{HT}_{3}$ receptors causes the emission of sensory signals to the centre of the vomit. When ondansetron binds to these receptors, it blocks the emesis produced by the release of serotonin. This drug is indicated in the control of nausea and vomiting induced by cytotoxic chemotherapy and radiotherapy, and for the prevention of postoperative nausea and vomiting. ${ }^{14}$ In a previous work recently published by us, there is a revision about the stability studies of ondansetron alone and in mixture with other drugs. ${ }^{15}$

Haloperidol has been found to be very efficient in controlling agitation with or without pain, nausea and/or vomiting of central origin, intestinal obstruction, and delirium. ${ }^{16}$ Haloperidol is a conventional antipsychotic drug, and it is one of the first medicines that were used in the 20th century to treat mental illness. The stability of this drug has been studied in $5 \%$ dextrose, ${ }^{17}$ and in admixtures has been previously described with tramadol, $^{8}$ diamorphine hydrochloride ${ }^{18}$ and scopolamine N-butyl bromide. ${ }^{5}$ Also, the compatibility of tertiary blends with haloperidol, tramadol and dexketoprofen, ${ }^{19}$ or haloperidol, tramadol and hyoscine,${ }^{20}$ has been analysed.

The aim of this research was to investigate the compatibility and stability of haloperidol-ondansetron at two levels of concentrations and stored at two different temperatures, all of these protected from the light.

\section{MATERIALS AND METHODS \\ Materials}

Commercial haloperidol ampoules of $5 \mathrm{mg} / \mathrm{mL}$ (Dr Esteve Laboratory, Barcelona, Spain) and ondansetron ampoules of $2 \mathrm{mg} / \mathrm{mL}$ (Fresenius Kabi, Barcelona, Spain) were used. Sodium chloride $0.9 \%$ was obtained from Fresenius Kabi. Methanol (HPLC grade) was purchased from Merck (Darmstadt, 
Table 1 Statistical evaluation of data for different stability studies

\begin{tabular}{|c|c|c|c|c|c|c|c|}
\hline \multicolumn{8}{|c|}{ Haloperidol $150 \mathrm{mg} / \mathrm{L}$-ondansetron $250 \mathrm{mg} / \mathrm{L}, 25^{\circ} \mathrm{C}$} \\
\hline \multirow[t]{2}{*}{ Haloperidol (mg/L) } & \multirow[t]{2}{*}{ Mean } & \multirow[t]{2}{*}{ SD } & \multirow[t]{2}{*}{ RSD (\%) } & \multirow[t]{2}{*}{ Minimum } & \multirow[t]{2}{*}{ Maximum } & \multicolumn{2}{|l|}{ Confidence level } \\
\hline & & & & & & Lower & Upper \\
\hline 3 & 34426.6 & 2631.4 & 7.64 & 29302 & 40185 & 32531 & 36322.1 \\
\hline 6 & 72808 & 3170.59 & 4.35 & 66262 & 81551 & 70912.5 & 74703.5 \\
\hline 7.5 & 103573 & 9905.25 & 9.56 & 84110 & 115569 & 101677 & 105468 \\
\hline 9 & 132389 & 7015.76 & 5.30 & 115031 & 140775 & 130493 & 134285 \\
\hline \multirow[t]{2}{*}{ Ondansetron (mg/L) } & \multirow[t]{2}{*}{ Mean } & \multirow[t]{2}{*}{ SD } & \multirow[t]{2}{*}{ RSD (\%) } & \multirow[t]{2}{*}{ Minimum } & \multirow[t]{2}{*}{ Maximum } & \multicolumn{2}{|l|}{ Confidence level } \\
\hline & & & & & & Lower & Upper \\
\hline 5 & 46911.5 & 4837.56 & 10.31 & 40269 & 56383 & 42505.3 & 51317.6 \\
\hline 10 & 126782 & 8952.36 & 7.06 & 113568 & 144000 & 122500 & 131064 \\
\hline 12.5 & 213784 & 20958.8 & 9.80 & 170712 & 244406 & 209378 & 218190 \\
\hline 15 & 282907 & 12159.7 & 4.30 & 253262 & 296246 & 278365 & 287448 \\
\hline \multicolumn{8}{|c|}{ Haloperidol $150 \mathrm{mg} / \mathrm{L}$-ondansetron $250 \mathrm{mg} / \mathrm{L}, 37^{\circ} \mathrm{C}$} \\
\hline \multirow[t]{2}{*}{ Haloperidol (mg/L) } & Mean & SD & RSD (\%) & Minimum & Maximum & Confidence level & \\
\hline & & & & & & Lower & Upper \\
\hline 3 & 34695.2 & 5055.33 & 14.57 & 27213 & 50498 & 32995.2 & 36395.2 \\
\hline 6 & 75862.1 & 4871.85 & 6.42 & 67074 & 83749 & 74129.7 & 77594.5 \\
\hline 7.5 & 98015.4 & 4211.78 & 4.30 & 87433 & 104577 & 96248.7 & 99782.1 \\
\hline 9 & 131384 & 11391.8 & 8.67 & 112838 & 152700 & 129684 & 133084 \\
\hline Ondansetron $\left(\mathrm{mg} / \mathrm{L}^{1}\right)$ & Mean & SD & RSD (\%) & Minimum & Maximum & Confidence level & \\
\hline & & & & & & Lower & Upper \\
\hline 5 & 54124.5 & 4978.36 & 9.20 & 45417.0 & 67052.0 & 50410.3 & 57838.7 \\
\hline 10 & 142591 & 10187.9 & 7.14 & 125569 & 164360 & 138948 & 146233 \\
\hline 12.5 & 199145 & 13553.1 & 6.81 & 178647 & 234189 & 195503 & 202787 \\
\hline 15 & 270662 & 20386.6 & 7.53 & 224855 & 308082 & 267088 & 274236 \\
\hline Haloperidol $300 \mathrm{mg} / \mathrm{L}$ & ansetron 40 & $5^{\circ} \mathrm{C}$ & & & & & \\
\hline Haloperidol (mg/L) & Mean & SD & RSD (\%) & Minimum & Maximum & Confidence level & \\
\hline & & & & & & Lower & Upper \\
\hline 3 & 32140.9 & 1936.97 & 6.02 & 28945 & 35592 & 26927.4 & 37354.3 \\
\hline 6 & 67809.2 & 2032.03 & 2.99 & 63921 & 71435 & 63078.1 & 72540.3 \\
\hline 9 & 99662.1 & 3550.02 & 3.56 & 90854 & 104148 & 94785.4 & 104539 \\
\hline 12 & 154558 & 7968.24 & 5.16 & 139751 & 170106 & 149960 & 159155 \\
\hline 15 & 199046 & 9161.04 & 4.60 & 184858 & 218365 & 194315 & 203777 \\
\hline Ondansetron (mg/L) & Mean & SD & RSD (\%) & Minimum & Maximum & Confidence level & \\
\hline & & & & & & Lower & Upper \\
\hline 4 & 33004.4 & 2071.03 & 6.27 & 28479 & 36324 & 22967.6 & 43041.2 \\
\hline 8 & 85759.5 & 5508.41 & 6.42 & 78115 & 94037 & 76296.7 & 95222.3 \\
\hline 12 & 149754 & 15704.3 & 10.49 & 122502 & 176570 & 139717 & 159791 \\
\hline 16 & 265035 & 14593.8 & 5.51 & 243688 & 290900 & 255572 & 274498 \\
\hline 20 & 348239 & 8922.38 & 2.56 & 332641 & 363157 & 338502 & 357976 \\
\hline Haloperidol $300 \mathrm{mg} / \mathrm{L}$ & ansetron 40 & $7^{\circ} \mathrm{C}$ & & & & & \\
\hline Haloperidol (mg/L) & Mean & SD & RSD (\%) & Minimum & Maximum & Confidence level & \\
\hline & & & & & & Lower & Upper \\
\hline 3 & 34390.7 & 5717.93 & 16.62 & 24508 & 50195 & 31564.5 & 37216.9 \\
\hline 6 & 74437.2 & 5594.48 & 7.52 & 64662 & 83112 & 71611 & 77263.4 \\
\hline 9 & 110952 & 10204.5 & 9.19 & 96905 & 138969 & 108126 & 113778 \\
\hline 12 & 151654 & 14133.3 & 9.32 & 132560 & 177108 & 148827 & 154480 \\
\hline 15 & 202465 & 15095.5 & 7.46 & 163237 & 222354 & 199639 & 205292 \\
\hline Ondansetron (mg/L) & Mean & SD & RSD (\%) & Minimum & Maximum & Confidence level & \\
\hline & & & & & & Lower & Upper \\
\hline 4 & 41394.3 & 8997.07 & 21.73 & 27092 & 66656 & 34902.1 & 47886.4 \\
\hline 8 & 106721 & 14494.8 & 13.58 & 79022 & 127928 & 100228 & 113213 \\
\hline 12 & 175981 & 17486.2 & 9.94 & 134287 & 219521 & 169488 & 182473 \\
\hline 16 & 254444 & 35293.2 & 13.87 & 178709 & 312767 & 247952 & 260937 \\
\hline 20 & 353304 & 34381.3 & 9.73 & 227277 & 390679 & 346812 & 359796 \\
\hline
\end{tabular}

RSD, Relative standard deviation. 


\begin{tabular}{|c|c|c|c|}
\hline Admixtures haloperidol-ondansetron $(\mathrm{mg} / \mathrm{mL})$ & Temperature & Drug & Regression equation ${ }^{23}$ \\
\hline \multirow[t]{3}{*}{$0.150-0.250$} & \multirow[t]{2}{*}{$25^{\circ} \mathrm{C}$} & Haloperidol & $\begin{array}{l}\text { Slope: } 15717.4 \pm 871.1^{*} \\
\text { Intercept: }-13829.8 \pm 5291.5^{*} \\
\mathrm{R}^{2}=0.991\end{array}$ \\
\hline & & Ondansetron & $\begin{array}{l}\text { Slope: } 23688.2 \pm 2983.7^{*} \\
\text { Intercept: }-84090.8 \pm 33566.6^{*} \\
\mathrm{R}^{2}=0.970\end{array}$ \\
\hline & $37^{\circ} \mathrm{C}$ & Ondansetron & $\begin{array}{l}\text { Slope: } 21284.1 \pm 1766.1^{*} \\
\text { Intercept: }-59512.8 \pm 19868.1^{*} \\
\mathrm{R}^{2}=0.986\end{array}$ \\
\hline \multirow[t]{3}{*}{$0.300-0.400$} & $25^{\circ} \mathrm{C}$ & Haloperidol & $\begin{array}{l}\text { Slope: } 14018.6 \pm 803.9^{*} \\
\text { Intercept: }-15524.5 \pm 7999.5^{*} \\
R^{2}=0.990\end{array}$ \\
\hline & \multirow[t]{2}{*}{$37^{\circ} \mathrm{C}$} & Haloperidol & $\begin{array}{l}\text { Slope: } 13778.8 \pm 494.0^{*} \\
\text { Intercept: }-9229.8 \pm 4915.2^{*} \\
\mathrm{R}^{2}=0.996\end{array}$ \\
\hline & & Ondansetron & $\begin{array}{l}\text { Slope: } 19288.6 \pm 960.8^{*} \\
\text { Intercept: }-45093.9 \pm 12746.5^{*} \\
R^{2}=0.993\end{array}$ \\
\hline
\end{tabular}

${ }^{*}$ SE for regression equation obtained by Statgraphics program.

Germany). Other chemicals and solvents were of analytical grade and were obtained from Merck. High-purity water (resistivity $18.2 \mathrm{M} \Omega \mathrm{cm}$ ) obtained by a Milli-Q water purification system (Millipore, Bedford, Massachusetts, USA) was used throughout this work.

\section{Preparation of sample solutions}

The concentrations of the mixtures were $0.25-0.15 \mathrm{mg} / \mathrm{mL}$ and $0.4-0.3 \mathrm{mg} / \mathrm{mL}$ of ondansetron and haloperidol, respectively, which were prepared in $0.9 \% \mathrm{NaCl}$ and conserved at $25^{\circ} \mathrm{C}$ and $37^{\circ} \mathrm{C}$ for each one, and a Selecta oven (Incudigit 19L 001246) was used for this purpose. Each one of the samples was stored in three elastomeric infusers protected from the light.

\section{Preparation of standard solutions}

For the first mixture mentioned above, four standards were prepared by adequate dilution from the sample $(0.25 \mathrm{mg} /$ $\mathrm{mL}$ ondansetron- $0.15 \mathrm{mg} / \mathrm{mL}$ haloperidol) to obtain different concentrations of between 5 and $15 \mathrm{mg} / \mathrm{L}$ for ondansetron and between 3 and $9 \mathrm{mg} / \mathrm{L}$ for haloperidol admixtures, respectively. In the same manner for the second mixture, five standards of solutions were prepared by adequate dilution from the sample $(0.4 \mathrm{mg} / \mathrm{mL}$ ondansetron- $0.3 \mathrm{mg} / \mathrm{mL}$ haloperidol) to obtain different concentrations of between 4 and $20 \mathrm{mg} / \mathrm{L}$ for ondansetron and between 3 and $15 \mathrm{mg} / \mathrm{L}$ for haloperidol admixtures, respectively. The standards were divided into different aliquot parts, stored in Eppendorf tubes and frozen until each day of analysis.

\section{Instrument and chromatographic conditions}

HPLC analysis was performed at room temperature $\left(\sim 25^{\circ} \mathrm{C}\right)$ using a Shimadzu LC-6A pump equipped with Rheodyne 7125 injection valve of $20 \mu \mathrm{L}$ and a Shimadzu SPD-6A spectrophotometric detector working at $254 \mathrm{~nm}$. The signal from the detector was recorded and integrated with a chromatography data system Shimadzu C-R6A chromatopac; a LiChrospher 100 C18 $(5 \mu \mathrm{m})$
LiChroCART 250-4 column was employed. The mobile phase consisted of methanol: $\mathrm{KH}_{2} \mathrm{PO}_{4} 0.05 \mathrm{M}$, adjusted to $\mathrm{pH} 3$ with $\mathrm{H}_{3} \mathrm{PO}_{3}(60: 40, \mathrm{v} / \mathrm{v})$ delivered at a flow rate of $1.0 \mathrm{~mL} / \mathrm{min}$. The sample injection volume was $20 \mu \mathrm{L}$, and triplicate injections were performed for every sample. The signal was recorded for $8 \mathrm{~min}$, and the retention times were 3.6 for ondansetron and $6.6 \mathrm{~min}$ for haloperidol.

\section{Physical stability study}

The physical stability of both drugs was determined by visual inspection of each sample control, with no colour change or appearance of turbidity, and no precipitation and particle agglomeration. Visual inspection was done before determining the concentrations of ondansetron and haloperidol by HPLC.

\section{Chemical stability study}

Stability of the mixture was defined as retention of at least $90 \%$ of the initial mixture concentration, which was defined as $100 \%$, and subsequent sample concentrations were expressed as a percentage of the initial concentration.

\section{Forced degradation analysis}

These studies are required to demonstrate specificity of stability indicating methods and also provide an insight into the degradation pathways and degradation products of the drug substance. $^{2122}$

For this purpose five studies were made over each drug solution: acid, base, heat, UV light and hydrogen peroxide.

\section{RESULTS AND DISCUSSION Accelerated degradation study}

The subsequent trials were carried out over each drug solution (6 mg/mL of ondansetron or $20 \mathrm{mg} / \mathrm{mL}$ of haloperidol).

pH study

Different amounts of $\mathrm{HCl} 1 \mathrm{M}$ or $\mathrm{NaOH} 1 \mathrm{M}$ (100, 250 and $500 \mu \mathrm{L}$ ) were added to aliquot of $500 \mu \mathrm{L}$ of each drug. Additions 

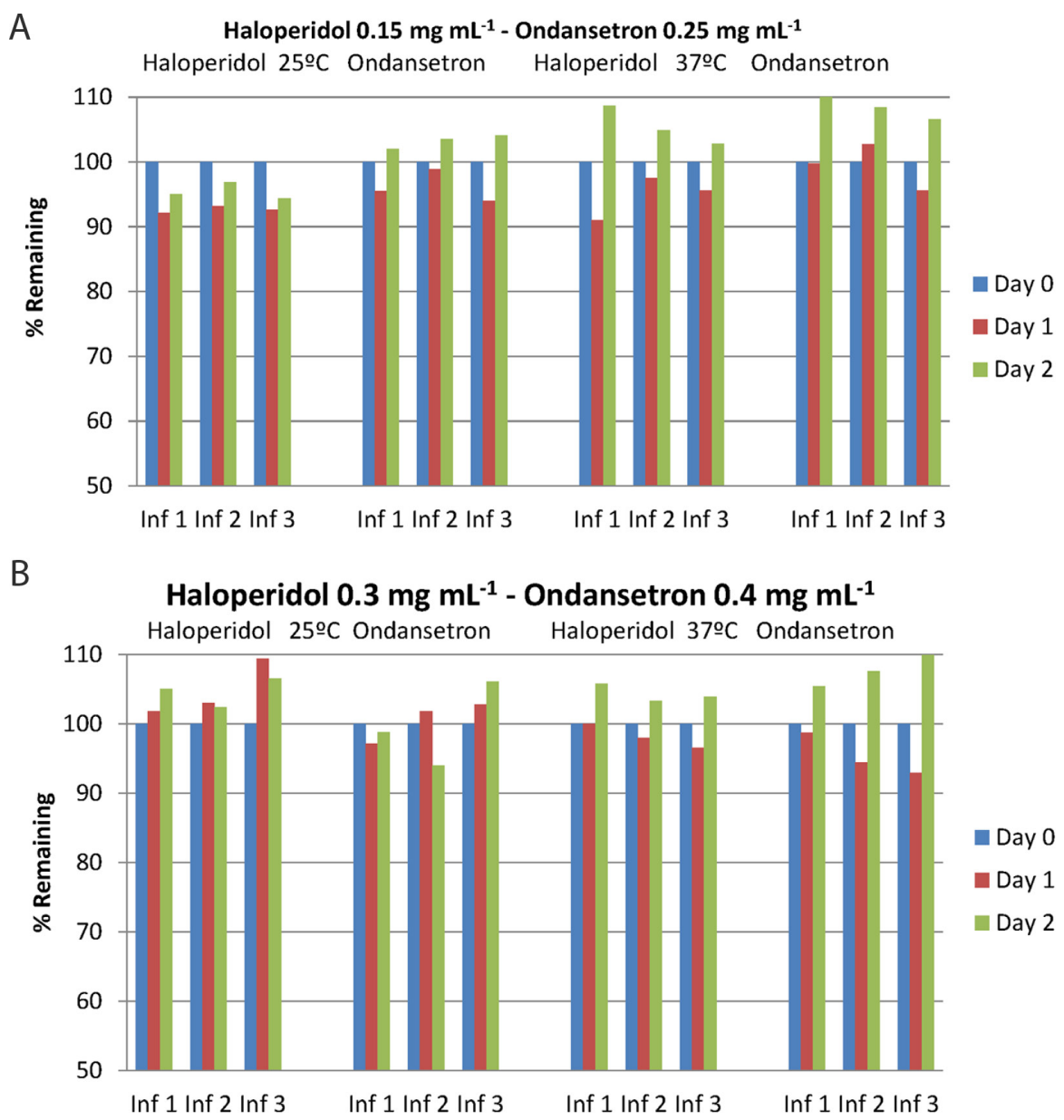

Figure $1(A, B)$ Percentages of mixtures remaining at $25^{\circ} \mathrm{C}$ and $37^{\circ} \mathrm{C}$.

of $\mathrm{HCl}$ and $\mathrm{NaOH}$ have not influenced the chromatographic signal of haloperidol. In the case of ondansetron, a new signal appears at $1.9 \mathrm{~min}$ when the $\mathrm{HCl}$ volume added was 250 or $500 \mu \mathrm{L}$, being it higher when the volume and the time increase. On the other hand, the addition of $\mathrm{NaOH}$ about ondansetron signal gives two new signals (1.8 and $2.6 \mathrm{~min}$ ). These signals enhanced with the volume of $\mathrm{NaOH}$ added and stayed constant with the time.

\section{Heat study}

Two samples of each drug were heated at $40^{\circ} \mathrm{C}$ and $60^{\circ} \mathrm{C}$ at different times (from 10 to $60 \mathrm{~min}$ ). No significant changes were observed in the chromatograms in all cases.

\section{UV light}

One sample of each drug was subject to UV irradiation for several days. The signal of the haloperidol diminished with the time of exposition. With respect to the ondansetron a new signal appears at $2.2 \mathrm{~min}$, and also increased with the time while the peak area at $3.6 \mathrm{~min}$ diminished with time.

\section{Oxidants}

Different amounts of $\mathrm{H}_{2} \mathrm{O}_{2} 3 \%(100,250$ and $500 \mu \mathrm{L})$ were added to aliquots of $500 \mu \mathrm{L}$ of each drug. No effects were observed for haloperidol, while for ondansetron two new signals appeared at 1.9 and $2.8 \mathrm{~min}$ and whose areas enhanced with the volume of oxidant added.

\section{Physical stability study}

The mixtures stored into infusers, initially clear and colourless, precipitated after 48 hours from its preparation.

\section{Chemical stability study}

Statgraphics Centurion XVI program ${ }^{23}$ was used for data analysis. Table 1 shows the statistical study of the data. Calibration curves were linear over the concentration range used, with acceptable correlation coefficients, as can be seen in table 2 . Figure $1 \mathrm{~A}, \mathrm{~B}$ shows the percentages remaining for each mixture at $25^{\circ} \mathrm{C}$ and $37^{\circ} \mathrm{C}$.

\section{CONCLUSIONS}

This study evaluated the stability and the compatibility of mixtures of haloperidol and ondansetron when stored in

\section{What this paper adds}

What is already known on this subject

- The admixtures of ondansetron and haloperidol are recommended for use in palliative care.

- The stability of these admixtures is not known.

What this study adds

- This study evaluated the stability and the compatibility of mixtures of haloperidol and ondansetron when stored in elastomeric infusors at two temperatures $\left(25^{\circ} \mathrm{C}\right.$ and $\left.37^{\circ} \mathrm{C}\right)$. 
elastomeric infusors at two temperatures $\left(25^{\circ} \mathrm{C}\right.$ and $\left.37^{\circ} \mathrm{C}\right)$. On the basis of our results, we suggest that subcutaneous infusion solutions, stored in elastomeric infusors and containing haloperidol-ondansetron (at the concentration ranges assayed), may be prepared and used with confidence for 48 hours after preparation.

Funding The authors thank the Consejería de Igualdad Salud y Políticas Sociales (Junta de Andalucía) for supporting this study (PI-0013-2013).

Competing interests None declared.

Provenance and peer review Not commissioned; externally peer reviewed.

(c) European Association of Hospital Pharmacists (unless otherwise stated in the text of the article) 2018. All rights reserved. No commercial use is permitted unless otherwise expressly granted.

\section{REFERENCES}

1 World Health Organization. "Who definition of palliative care", 2012. Retrieved March 16.

2 Doran J. NRAHS Clinical Standards Committee. Northern Rivers Area Health Service. Palliative care pain management. Practice guidelines. 2005. http://www.pallitivedrugs. com

3 Grassby PF, Hutchings L. Drug combinations in syringe drivers: the compatibility and stability of diamorphine with cyclizine and haloperidol. Palliat Med 1997:11:217-24.

4 Vermeire A, Remon JP, Schrijvers D, et al. A new method to obtain and present complete information on the compatibility: study of its validity for eight binary mixtures of morphine with drugs frequently used in palliative care. Palliat Med 2002:16:417-24.

5 Barcia E, Reyes R, Luz Azuara M, et al. Compatibility of haloperidol and hyoscine- $N$ butyl bromide in mixtures for subcutaneous infusion to cancer patients in palliative care. Support Care Cancer 2003:11:107-13.

6 Good PD, Schneider JJ, Ravenscroft PJ. The compatibility and stability of midazolam and dexamethasone in infusion solutions. J Pain Symptom Manage 2004;27:471-5.

7 Barcia E, Reyes R, Azuara ML, et al. Stability and compatibility of binary mixtures of morphine hydrochloride with hyoscine-n-butyl bromide. Support Care Cancer 2005;13:239-45.
8 Negro S, Martín A, Azuara ML, et al. Stability of tramadol and haloperidol for continuous subcutaneous infusion at home. J Pain Symptom Manage 2005;30:192-9.

9 Negro S, Reyes R, Azuara ML, et al. Morphine, haloperidol and hyoscine N-butyl bromide combined in s.c. infusion solutions: compatibility and stability. Evaluation in terminal oncology patients. Inter J Pharma 2006;307:278-84.

10 Destro M, Ottolini L, Vicentini L, et al. Physical compatibility of binary and ternary mixtures of morphine and methadone with other drugs for parenteral administration in palliative care. Support Care Cancer 2012;20:2501-9.

11 Fernandez-Campos F, Mallandrich M, Calpena AC, et al. Stability studies of binary and ternary mixtures containing morphine, midazolam, levomepromazine and hyoscine butylbromide for parenteral administration. J Pharm Pharmacol 2013;65:379-89.

12 Bosch María E, Fuensanta SR, Catalina BO. Binary mixtures of morphine and furosemide: Compatibility and stability at different concentrations. Indian Journal of Pharmaceutical Education and Research 2015;49:575-81.

13 Dickman A, Bickerstaff M, Jackson R, et al. Identification of drug combinations administered by continuous subcutaneous infusion that require analysis for compatibility and stability. BMC Palliat Care 2017;16:22-8.

14 Currow DC, Coughlan M, Fardell B, et al. Use of ondansetron in palliative medicine. J Pain Symptom Manage 1997:13:302-7.

15 Espinosa Bosch M, Ruiz Sánchez AJ, Sánchez Rojas F, et al. Review of analytical methodologies for the determination of $5-\mathrm{HT}_{3}$ receptor antagonists. Microchemical J 2017;132:341-50

16 Lord M, Clarke R. Palliative care. Controlling gastrointestinal symptom. Pharm J 1995:254:511-4.

17 Das Gupta V, Stewart KR. Stability of haloperidol in 5\% dextrose injection. Am J Hosp Pharm 1982;39:292-4.

18 Collins AJ, Abethell JA, Holmes SG, et al. Stability of diamorphine hydrochloride with haloperidol in prefilled syringes for continuous subcutaneous administration. J Pharm Pharmacol 1986;38:51P.

19 Salmerón-García A, López-López E, Román E, et al. Development of an LC-DAD method for analysis of dexketoprofen, tramadol and haloperidol. Study of the stability of mixtures used for patient-controlled analgesia. Chromatographia 2008:68:767-72.

20 Negro S, Martín A, Azuara L, et al. Compatibility and stability of ternary admixtures of tramadol, haloperidol, and hyoscine. J Palliat Med 2010;13:273-7.

21 Singh S, Junwal M, Modhe G, et al. Forced degradation studies to assess the stability of drugs and products. Trends Anal Chem 2013;49:71-8.

22 Blessy M, Patel RD, Prajapati PN, et al. Development of forced degradation and stability indicating studies of drugs-a review. J Pharm Anal 2014;4:159-65.

23 Statgraphics $®$ Centurion XVI, () 2010 StatPoint Technologies, Inc. http://www. STATGRAPHICS.com 